\title{
Atypical Breast Papilloma
}

National Cancer Institute

\section{Source}

National Cancer Institute. Atypical Breast Papilloma. NCI Thesaurus. Code C36089.

An intraductal papilloma of the breast characterized by the presence of focal epithelial atypia. 